\title{
PENYUSUAN SUSU IBU SEBAGAI MEDIUM PENYELESAIAN PERMASALAHAN PENGAMBILAN ANAK ANGKAT DI MALAYSIA
}

\author{
Normadiah binti Daud ${ }^{1}$ \\ ${ }^{I}$ Universiti Sultan Zainal Abidin \\ E-mail: normadiah@unisza.edu.my
}

\begin{abstract}
Abstrak: Seramai 6,259 orang anak angkat telah didaftarkan di seluruh Malaysia sejak tahun 2010. Ia semakin meningkat dari tahun ke tahun. Kajian telah membuktikan pasangan Melayu yang beragama Islam adalah golongan yang paling ramai mengambil anak angkat. Persoalannya bagaimanakah keluarga angkat yang beragama Islam ini mampu menjaga batasbatas pergaulan mereka dengan anak tersebut terutamanya apabila anak tersebut meningkat balig? Perkara ini telah menjadi barah dalam kehidupan masyarakat Islam hari ini. Justru itu, kajian ini dilakukan untuk mencari jalan penyelesaian kepada permasalahan tersebut berdasarkan kepada pengamalan ibu susuan yang pernah dilakukan pada zaman Rasul SAW. Di samping itu kajian ini juga memuatkan syarat-syarat pengambilan anak angkat di Malaysia dan syarat-syarat untuk menjadi ibu susuan menurut Islam. Dengan cara ini pasangan yang tidak mempunyai anak akan mendapat anak angkat dan pada masa yang sama tuntutan syariat juga dapat dipelihara. Metode kajian ini ialah keperpustakaan dan keseluruhan fakta adalah berteraskan kepada kitab fiqh, sirah, tafsir dan hadis. Hasilnya, ternyata pengamalan ibu susuan dalam pelbagai cara yang dibenarkan oleh syarak dan berteraskan kepada apa yang pernah dilakukan oleh Rasul SAW mampu menyelamatkan masyarakat daripada melakukan dosa di rumah sendiri dan menjaga keutuhan masyarakat muslim dengan batas-batas pergaulan yang telah digariskan dalam Islam.
\end{abstract}

Kata Kunci : Ibu Susuan, Anak Angkat, Sunnah

\section{PENDAHULUAN}

$\mathrm{P}$ enyusuan susu ibu merupakan satu amalan yang sangat mulia dan sangat dituntut dalam Islam. Penyusuan atau dalam bahasa arab al-rad̄ ' $a h^{1}$ merupakan satu cabang ilmu yang terdapat dalam bidang syariah. Penyusuan mempunyai kepentingannya yang tersendiri serta memberi manfaat besar kepada anak yang disusui atau ibu yang menyusukannya. Susu ibu ternyata mempunyai bahan nutrien dan zat yang sangat bermanfaat kepada kesehatan dan pertumbuhan bayi ${ }^{2}$ serta pelaksanaannya juga dapat menyehatkan ibu

\footnotetext{
${ }^{1}$ Ibn Manzūr, Muḥammad ibn Mukram. 2003. Lisān al- 'Arab. Kaherah: Dār al-Hadīth. p.481-482.

2 Syeikh Alaudeen. 1996. Penyusuan Ibu Aspek Pemakanan, Perkembangan dan Kesihatan Bayi. Kuala Lumpur: Dewan Bahasa dan Pustaka. p.187.
} 
yang menyusu. ${ }^{3}$ Selain daripada itu penyusuan susu ibu juga mempunyai keistimewaannya yang tersendiri dari pelbagai sudut seperti sains, ekonomi dan sosial. Menurut perspektif Islam pula, penyusuan merupakan perkara penting karena ia mempunyai implikasi yang besar terhadap pensabitan nasab atau keturunan. ${ }^{4}$ Bahkan pensyariatannya juga adalah jelas di dalam al Qur'ān dan sunnah. Apa yang paling penting amalan penyusuan susu ibu ini terutamanya melibatkan ibu susuan dilalui sendiri oleh Baginda Rasulullah SAW ketika usia bayinya. Di mana Nabi Muhammad SAW sendiri meminum susu dari ibu susuannya yang dibayar upah yaitu Halimah al-Sa'diyyah dan Thuwaibah al-Aslamiyyah. Penyusuan Rasulullah SAW ini merupakan satu teladan yang terbaik kepada semua umat Islam. Sejak kecil beliau diperkenalkan dengan susu ibu. Setelah dilahirkan 8 hari baginda telah disusui oleh Thuwaibah al-Aslamiyyah. Seterusnya beliau disusui oleh seorang perempuan mulia dari Bani Sa'ad. Bani Sa'ad terletak jauh di pedalaman dan terkenal sebagai satu suku yang mengambil anak susuan. ${ }^{5}$ Persekitaran desanya bersih dan nyaman memberikan kesehatan dan keamanan kepada bayi. ${ }^{6}$

Penyusuan Rasulullah SAW ini menjadikan Baginda mahram kepada Halimah alSa‘diyyah dan Thuwaibah al-Aslamiyyah untuk selama-lamanya. Justru amalan mulia sepatutnya diambil pengajarannya oleh semua pasangan yang ingin mengambil anak angkat supaya menyusukan anak tersebut terlebih dahulu dengan syarat-syarat yang telah ditetapkan dalam Islam. Persoalan ini diketengahkan karena menurut Jabatan Pendaftaran Negara, pasangan Melayu muslim adalah mereka yang paling ramai mengambil anak angkat. ${ }^{7}$ Justru mereka perlu didedahkan dengan pengamalan ibu susuan ini untuk memastikan pergaulan mereka dengan anak angkat tersebut mengikut landasan Islam yang sebenarnya. Untuk merealisasikan objektif ini, penulisan ini akan membincangkan tentang pengertian penyusuan susu ibu, dalil yang mengharuskan pelaksanaan ibu susuan, syarat-syarat penyusuan yang mengharamkan, syarat-syarat pengambilan anak angkat di Malaysia dan interpertasi sunnah nabawiyah dalam mewujudkan Hubungan Mahram dengan Anak Angkat dan Anak Susuan.

\section{HASIL DAN PEMBAHASAN}

\section{Pengertian Penyusuan Susu Ibu}

Pengertian penyusuan susu ibu boleh dibahagikan kepada dua yaitu pengertian menurut bahasa dan menurut istilah syarak. Menurut bahasa penyusuan berasal daripada perkataan

\footnotetext{
${ }^{3}$ Abdul Hamid Arshat. 1991. Baka dan Zuriat. Kuala Lumpur: Syarikat S. Abdul Majeed. p.129.

${ }^{4}$ al-Māwardī. 1996. p.43; Zaydān. 2003. p.468; al-Shāfi'ī, Abū 'Abd Allah Muhammad ibn Idrīs. t.th. al-Umm, Jordan: Bayt al-Afkār al-Dawliyyah. p.888-889; Abū al-'Abbās, Shams al-Dīn Muḥammad. 1984. Nihāyat al-Muhtāj 'ilā Sharh al-Minhāj fì madhhab al-Imām al-Shāfi ‘ì. Vol. 7. Bayrūt: Dār al-Fikr. pp.211-212.

${ }^{5}$ Muhammad Husain Haekal. 1989. Sejarah Hidup Nabi Mohammad. Kuala Lumpur: Dewan Bahasa dan Pustaka. p.53.

${ }^{6}$ Choudhry, G.W. 1993. The Prophet Muhammad, His Life and Eternal Message. Kuala Lumpur: WHS Publication Sdn. Bhd. p.20.

${ }^{7}$ Anon.Melayu paling ramai mohon anak angkat, 19.5.2011, http://www.utusan.com.my/utusan/info
} 
radi' $a$ dan rada' $a$ iaitu penyusuan anak oleh ibunya. ${ }^{8}$ Perempuan yang menyusukan anak digelar al-murḍi $i^{\prime} a h$ dan anak yang disusui pula digelar $a l-r a d \bar{l}^{‘} \cdot 9$

Menurut istilah syarak, terdapat beberapa pandangan tertentu daripada berkenaan beberapa maksud dan takrif penyusuan. Antaranya mazhab Hanafi mentakrifkan penyusuan sebagai meminum susu perempuan-perempuan adam pada waktu tertentu. ${ }^{10}$ Mazhab Maliki pula berpendapat penyusuan ialah memasukkan susu perempuan sama ada sesudah mati atau perempuan kecil meskipun melalui puting atau alat bantuan makanan atau susu yang bercampuran (dengan syarat hendaklah susu melebihi daripada benda lain) dengan makanan lain dalam tempoh tidak melebihi dua tahun. ${ }^{11}$ Mazhab Shāfi ${ }^{‘} \mathbf{1}$ yang menjadi pegangan kebanyakan umat Islam di Malaysia menyatakan penyusuan ialah sesuatu perkara yang digunakan untuk memasukkan susu perempuan ke dalam hidangan kanak-kanak yang memberi kesan kepada pembesaran. ${ }^{12}$ Seterusnya mazhab Hanbali berpendapat penyusuan ialah memasukkan susu secara semula jadi atau alat bantuan minuman kepada siapa yang umurnya tidak melebihi dua tahun. ${ }^{13}$ Berdasarkan maksud dan takrif yang telah dibincangkan, dapat dirumuskan bahwa pengertian penyusuan susu ibu mengikut fuqaha ialah memasukkan susu perempuan ke dalam rongga kanak-kanak dengan perantaraan payudara dengan syarat-syarat yang tertentu. ${ }^{14}$

\section{Dalil yang Mengharuskan Pengamalan Ibu Susuan}

Penyusuan susu ibu adalah amalan yang baik dan digalakkan oleh Islam bagi menjamin kesehatan tumbuh besar bayi dan pemulihan kesehatan ibu selepas melahirkan bayi. Terdapat dalil-dalil daripada al-Qur'ān dan hadis yang menyokong dan menggalakkan amalan penyusuan tersebut. Firman Allah SWT: Dan ibu-ibu hendaklah menyusukan anak-anak mereka selama dua tahun genap, yaitu bagi orang yang ingin menyempurnakan penyusuan itu.

Dalam ayat ini, Allah SWT menyatakan dengan jelas, bahwa para ibu hendaklah menyusukan anak mereka selama dua tahun bagi mereka yang berkemampuan dan mengingininya. Namun begitu, tidak menjadi kesalahan sekiranya mereka ingin mengupah orang lain untuk menyusukan anak mereka karena sebab-sebab tertentu. ${ }^{15}$ Firman Allah SWT,

\footnotetext{
${ }^{8}$ Sa'dī Abū Jayb. 1988. al-Qāmūs al- Fiqhī Lughotan wa Iștilāḥan. Damsyiq: Dār al- Fikr. p.149; Ibn Manẓūr, Muḥammad ibn Mukram. 2003. Lisān al- 'Arab. Kaherah: Dār al-ḥadīth. p.481-482.

${ }^{9}$ al-Rāzī, Muhammad ibn Abī Bakr ibn 'Abd al-Qadīr. 1995. Mukhtar al-Șiḥah. Bayrūt: Maktabat Lubnan. p.69.

${ }^{10}$ al-Ghunaymī, 'Abd al-Ghanī al-Dimashqī al-Maydānī al-Hanafĩ. 1993. al-Lubāb fì Sharh al-Kitāb, Bayrūt: Maktabah al'Ilmiyyah. p.31; al-Zaylā‘'̄, Jamāl al-Dīn Abū Muhammad 'Abd Allāh al-Hanafì. 2000. Tabyīn al-Haqā’iq Sharh Kanz alDaqū'iq. Bayrūt: Dār al-Kutub al-'Ilmiyyah. p.620.

${ }^{11}$ al-Dardīr, Abū al-Barākāt Aḥmad ibn Muḥammad. t.th. al-Sharh al-Saghir 'alā Aqrab al-Masālik ila Madhhab al-Imām Malik. Bayrūt: Dār al-Ma‘ārif. p.719-721.

12 al-Sharbīnī, Muḥammad al-Khațīb. 1978. Mughnī al-Muhtāj ilā Ma 'rifat Ma 'ānī Alfāz al-Minhāj. Vol. 3. Bayrūt: Dār Ihyā' al-Turāth al-'Arabī. p.414.

${ }^{13}$ al-Bahūīī, Manșūr ibn Idrīs. 2003. Kashshāf al-Qinā' 'an Matn al-Iqnā'. Arab Saudi: Dār 'Alam al-Kutub. p.2795.

${ }^{14} \mathrm{Ibnu}$ 'Ābidīn, Muhammad Amīn. 1992. Hāshiyat Radd al Mukhtār 'ala al-Durr al Mukhtār: Sharh Tanwīr al Abșār. Vol.3. Bayrūt: Dār al- Fikr. p.209; al-Sharbīnī. 1978. pp.414-416.

${ }^{15}$ Riḍā, Muhammad Rashid. 2005. Tafsīr al-Manār. Vol. 2. Bayrūt: Dār al-Kutub al-‘Ilmiyyah. p.409.
} 
maksudnya: Dan jika kamu hendak beri anak-anak kamu menyusu kepada orang lain, maka tidak ada salahnya bagi kamu apabila kamu serahkan (upah) yang kamu mau beri itu dengan cara yang patut. Dan bertakwalah kamu kepada Allah, serta ketahuilah, sesungguhnya Allah senantiasa melihat akan apa jua yang kamu lakukan.

Selain daripada ayat al-Qur'ān, terdapat banyak hadis Rasulullah SAW yang menceritakan tentang kelebihan penyusuan susu ibu dan pensabitan mahram akibat penyusuan. Antara hadisnya ialah Rasulullah SAW bersabda:

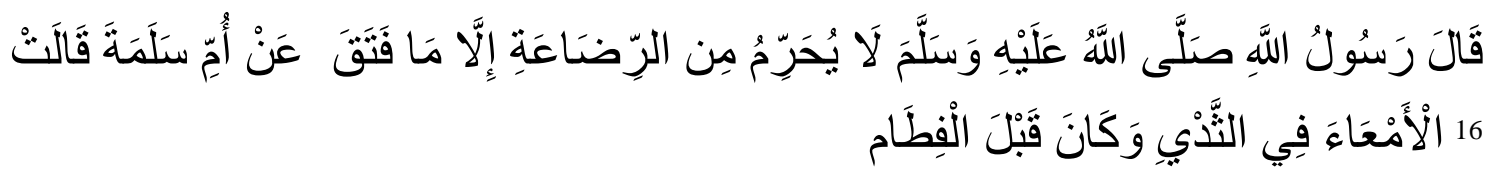

Maksudnya:

Ummu Salamah berkata: Rasulullah SAW. berkata, seseorang itu tidak menjadi mahram penyusuan kecuali dia telah kenyang (meminum susu daripada payudara) dan ia berlaku dalam tempoh penyusuan.

Sabda Rasulullah SAW lagi:

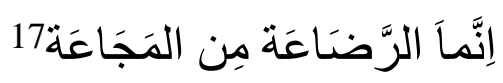

Maksudnya: Sesungguhnya penyusuan itu daripada sebab kelaparan.

Seterusnya Baginda SAW bersabda:

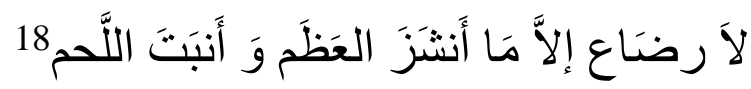

Maksudnya: Tiada penyusuan melainkan penyusuan melainkan yang menguatkan tulang dan menumbuhkan daging.

Ayat al-Qur'ān dan hadis tersebut jelas menyatakan bahwa penyusuan susu ibu adalah digalakkan karena ia adalah makanan terbaik untuk bayi dan membantu tumbesaran mental dan fizikal bayi yang sehat. Walau bagaimanapun, penyusuan dalam Islam tidak hanya memfokuskan kepada isu kesehatan, tetapi juga menitikberatkan pensabitan nasab anak susuan dengan ibu susuannya, yang jika cukup rukun dan syarat-syaratnya menyebabkan sabitnya nasab anak susuan tersebut kepada ibu susuannya. Ayat yang berkaitan dengan pensabitan nasab disebabkan susu ibu dinyatakan dalam firman Allah SWT, maksudnya: diharamkan kepada kamu berkahwin dengan (perempuan-perempuan yang berikut): ibu-ibu kamu, dan anak-anak kamu, dan saudara-saudara kamu, dan saudara-saudara bapa kamu, dan saudarasaudara ibu kamu, dan anak-anak saudara kamu yang lelaki, dan anak-anak saudara kamu yang perempuan, dan ibu-ibu kamu yang telah menyusukan kamu.

Berkaitan dengan pengamalan ibu susuan ini juga, Rasulullah SAW bersabda lagi:

\footnotetext{
${ }^{16}$ al-Tirmidhī. Sunan al-Tirmidhī, kitāb al-riḍā', bab al-Raḍa 'ah lā tuharrim illā Fì Sighār dūn Hawlaynī, no. hadis: 1152.

17 al-Muslim, Șahīh Muslim, kitāb al riḍà', bab al-raḍà'ah min al-majā 'ah, no hadis: 1455.

${ }^{18}$ al San'ān̄i, Muhammad ibn Ismail al-Amir. 2005. Subul al- Salām. Kitāb al Riḍā', no hadis: 1078.
} 


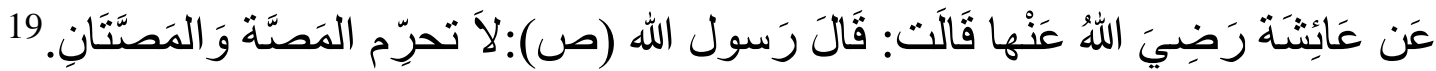

Maksudnya: diriwayatkan daripada 'Aishah RA katanya, Rasulullah SAW telah bersabda: Tidak diharamkan nikah oleh satu dan dua hisapan.

\section{Ibu Susuan}

Ibu susuan ialah seseorang yang diupah oleh seorang suami daripada saudara mereka atau seseorang yang ajnabì (asing) bagi menyusukan anak mereka dalam tempoh tertentu. Keadaan yang sama juga terjadi apabila seseorang wanita mengambil seseorang anak angkat kemudian disusukan anak tersebut dengan susunya sendiri. Penyusuan ini memberi kesan yang mendalam dalam pensabitan nasab. Ia menyebabkan anak yang disusui menjadi mahram kepada ibu susuannya dan keturunannya. Pengharaman ini terjadi sekiranya mengikut rukun dan syaratsyarat yang ditentukan oleh syarak. Penyusuan ibu susuan ini juga terbahagi kepada beberapa hukum berdasarkan kepada keadaan bayi dan ibu yang menyusu.

\section{Rukun Penyusuan yang Mengharamkan}

Antara perkara yang terlibat dengan syarat yang telah ditetapkan oleh syarak bagi mensabitkan pengharaman susuan adalah seperti orang yang menyusukan, bayi yang disusukan dan kadar susuan yang mengharamkan. ${ }^{20}$

\section{Orang yang Menyusukan}

Orang yang menyusukan mestilah seorang wanita. Menurut pendapat mazhab Shafi' $i$ dan Hanafi ${ }^{21}$, disyaratkan perempuan yang menyusukan itu telah mencapai sembilan tahun atau telah mencapai umur baligh. Walau bagaimanapun mengikut pandangan Ibn Rushd daripada mazhab Maliki, mereka tidak mensyaratkan perempuan atau ibu yang menyusukan anak mencapai usia baligh. ${ }^{22}$ Menurut Musțafā al- Zarqā’' dalam fatwanya, perempuan yang tua dan telah putus haid juga disabit pengharaman sekiranya seseorang bayi meminum susu daripadanya dengan syarat cukup lima kali kenyang. Demikian juga halnya jika seseorang bayi

\footnotetext{
${ }^{19}$ al-Muslim, Șah̄ịh Muslim, kitab al-ridā'; bab mașsoh wa mașsotān, no. hadis: 1450.

${ }^{20}$ al-Ghazālī, Abū Ḥāmid Muḥammad bin Mạ̣mūd. 2001. al-Wașịt Fī al-Madhhab. Vol. 3. Bayrūt: Dār-al Kutub al 'Ilmiyyah. p.394-398; al-Ḥusayn̄̄, Taqī al-Dīn Abū Bakr ibn Muhammad. 1995. Kifāyat al-Akhyār. Bayrūt: Dār al-Khayr. p.434-437,

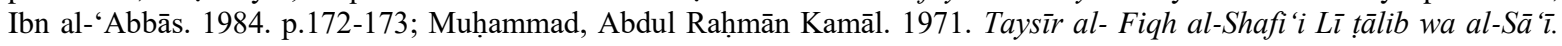
Bayrūt: Dār al- Kutub al-'Ilmiyyah. p.343.

${ }^{21}$ Op.cit.Sharbīn̄̄, Muḥammad al-Khațīb. Mughnī al-Muhtāj ilā Ma 'rifat Ma ‘ān̄̄ Alfāz al-Minhāj p.414.

${ }^{22}$ Ibnu Rushd, Abū al-Walīd Muhammad bin Aḥmad. Bidāyat al-Mujtaḥid fì Nihāyat al Muqtașid, Vol.2. Dār al-Fikr. p.30.
} 
meminum susu daripada seseorang perempuan yang masih dara. Ini karena tidak disyaratkan untuk mensabitkan pengharaman penyusuan itu dengan sebab melahirkan. ${ }^{23}$

Sekiranya susu tersebut datang daripada hewan, maka ia tidak mensabitkan pengharaman. Begitu juga, jika susu tersebut datangnya daripada seorang lelaki yang boleh mengeluarkan susu daripada dirinya walaupun diminum dengan kadar yang banyak, ia tetap tidak mengharamkan. Pendapat ini disokong oleh ulama mazhab Maliki ${ }^{24}$ dan Hanbali. ${ }^{25}$

Berkaitan dengan perempuan yang menyusui pula, beliau hendaklah dalam keadaan hidup ketika menyusukan bayi tersebut, walau bagaimanapun terdapat pelbagai pendapat ulama mengenainya. Mazhab Shāfi ${ }^{\prime 26}$ mensyaratkan perempuan tersebut mestilah hidup semasa penyusuan dilakukan. Sekiranya perempuan tersebut meninggal dunia semasa penyusuan dilakukan, maka ia tidak mensabitkan pengharaman. Menurut mereka, sekiranya seseorang bayi mengambil susu yang diperah daripada mayat seorang wanita, ia tidak mensabitkan pengharaman nasab. Ini karena susu mayat adalah tidak halal. ${ }^{27}$

\section{Syarat Usia Bayi Yang Disusukan}

Para ulama berselisih pendapat dalam menentukan umur bayi yang menyebabkan pengharaman antara ibu susuan dan anak susuan. Menurut pendapat mazhab Shāfi ${ }^{-28}{ }^{28}$ Abū Yūsof dan Mohammad daripada mazhab Hanafi ${ }^{29}$, mazhab Hanbali, satu riwayat dalam mazhab Malik, Umar, Ali, Ibnu Umar, Ishaq, Auzā'i dan Abū Thawr ${ }^{30}$ iaitu anak yang disusukan oleh seorang perempuan hendaklah berumur tidak lebih daripada dua tahun. Pendapat ini disandarkan kepada firman Allah, maksudnya: dan ibu-ibu hendaklah menyusukan anak-anak mereka selama dua tahun genap, iaitu bagi orang yang ingin menyempurnakan penyusuan itu 31

Maka sekiranya penyusuan dilakukan kepada bayi yang berusia lebih dari dua tahun, pengharaman tidak akan disabitkan. Selain daripada pendapat mazhab al-Shaf'i, ia juga disokong oleh sebahagian fuqaha yang lain seperti mazhab Hanafi, mazhab Maliki ${ }^{32}$ dan mazhab Hanbali. ${ }^{33}$ Walau bagaimanapun, pendapat yang masyhur dalam kalangan mazhab Malik ada menyatakan dua tahun adalah tempoh minimum dan tiada had minima tempoh penyusuan. Mereka menyebut sekiranya berlaku penyusuan selepas tempoh dua tahun dalam

\footnotetext{
${ }^{23}$ al -Zarqā’’, Mușțafā. 2004. Fatāwā Muștafāa al-Zarqā’’. Damsyiq: Dār al-Qalam. p. 293-294.

${ }^{24}$ al-Dusūqī, Shams al- Dīn Muhammad al-'Arafah. T.th. Hāshiyat al-Dusūqī 'alā al- Sharh al-Kabīr. Vol.2. T.tp: Dār alKutub al-'Arabiyyah. p.63-65.

${ }^{25}$ Op.cit.al-Husayn̄̄, Taq̄i al-Dīn Abū Bakr ibn Muhammad. Kifāyat al-Akhyārr. p.435.

${ }^{26}$ Op.cit.Sharbīn̄̄, Muḥammad al-Khațīb. Mughnī al-Muhtāj ilā Ma 'rifat Ma 'ānī Alfāz al-Minhājj. p 414; op.cit. al -Shāfi'ī, Abū 'Abd Allah Muhammad ibn Idrīs. al-Umm. p.894.

27 ibid. p.414; ibid. p.894.

${ }^{28}$ Ibid. p.892; ibid. p.414.

${ }^{29}$ al-Kāsān̄̄, 'Alā' al- Dīn, Abu Bakr ibn Mas'ūd. 1986. Badā'i ' al-Sanā'i'. Vol. 4. Bayrūt: Dār al-Kutub al'Ilmiyyah. p. 402.

${ }^{30}$ Ibn Qudāmah, 'Abd Allah ibn Ahmad. 2004. al-Mughnī. Vol. 2. Ammān: Bayt al-Afkār al-Dawliyyah. p.1974.

31 al-Qur'ān, al-Baqarah 2:233.

32 Op.cit. al-Dusūqī, Shams al- Dīn Muhammad al-‘Arafah. Hāshiyat al-Dusūqū 'alā al-Sharh al-Kabīr. p.503.

${ }^{33}$ Op.cit. al-Bahụūtī, Manșūr ibn Idrīs. Kashshāf al-Qinā' 'an Matn al-Iqnā' ' p.110.
} 
TAMADDUN : Jurnal Pendidikan dan Pemikiran Keagamaan

P-ISSN : 1693-3941; E-ISSN : 2722-2632

Vol. 22 No.1 Bulan Januari Tahun 2021

jarak yang hampir seperti dua tahun sebulan atau dua bulan, masih terjadi penyusuan yang mengharamkan. ${ }^{34}$

Selain daripada ayat di atas, mereka berhujah dengan beberapa hadis lain seperti hadis yang diriwayatkan oleh Ibn ‘Abbās RA.

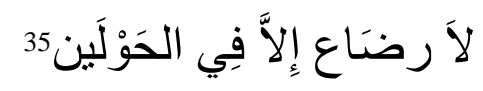

Maksudnya: Tiada penyusuan kecuali dalam tempoh dua tahun"

Hadis kedua yang diriwayatkan oleh al-Tirmidhī pula merupakan hadis hasān sahīh.

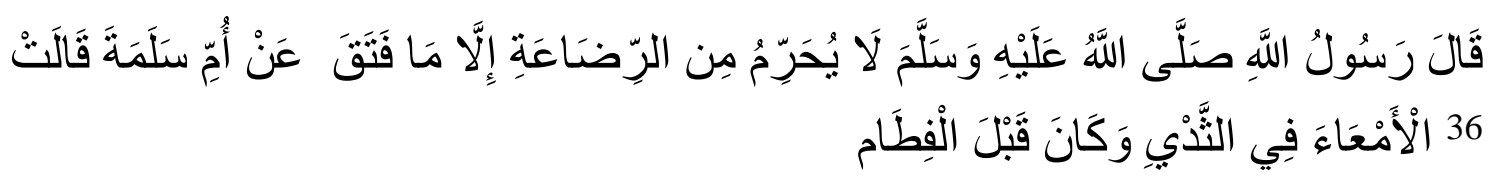

Maksudnya: Ummu Salamah berkata: Rasullullah SAW. bersabda, seseorang itu tidak menjadi mahram penyusuan kecuali dia telah kenyang (meminum susu daripada payudara) dan ia berlaku dalam tempoh penyususan.

Hadis ini menyatakan penyusuan yang menyebabkan terjadinya anak susuan itu sebagai mahram ialah dalam tempoh penyusuan iaitu sebelum dua tahun. Hadis ketiga:

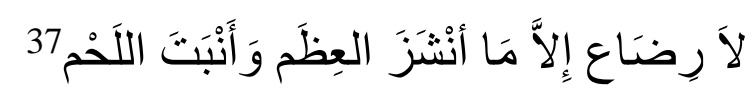

Maksudnya: Tidak ada hukum susuan melainkan penyusuan yang menguatkan tulang dan menumbuhkan daging.

Hadis ini memberi erti bahawa penyusuan itu hendaklah boleh menguatkan daging dan menumbuhkan tulang yaitu dalam tempoh usia dua tahun. ${ }^{38}$ Secara kesimpulannya, kesemua pandangan fuqaha dan hadis yang dinyatakan membawa erti penyusuan bayi yang menyebabkan berlaku mahram penyusuan ialah dalam tempoh usia bayi sebelum dua tahun. Ini berarti penyusuan kanak-kanak selepas usia dua tahun dan penyusuan orang dewasa tidak mengharamkan. Pendapat ini juga disebut oleh Ibn al- Qayyim dan disokong oleh beberapa para sahabat seperti Ibn Mas'ūd. Ibn 'Abbās, Abu Hurayrah, Sa‘̄̄d bin al-Musayyib dan lainlain lagi. ${ }^{39}$

\section{Syarat Kadar Penyusuan}

Bagi menentukan kadar atau bilangan penyusuan yang haram disebabkan penyusuan, para ulama telah berselisih pendapat kepada tiga pandangan. Pandangan pertama, mazhab Hanafi ${ }^{40}$

\footnotetext{
${ }^{34}$ Op.cit. al-Dusūqī, Shams al- Dīn Muhammad al-‘Arafah. Hāshiyat al-Dusūqū 'alā al- Sharh al-Kabīr. p.503.

${ }^{35}$ al San'ānī, Muhammad ibn Ismail al-Amir. 2005. Subul al-Salām. kitāb al-rị̣ā', no hadis: 1073.

36 al-Tirmidhī, Sunan al-Tirmidhī, kitāb al- riḍ̄ā', no hadis: 1152.

${ }^{37}$ al-Șan‘ān̄i, Muhammad ibn Ismail al-Amir. 2005. Subul al-Salām, kitāb al-Riḍ̄à', no hadis: 1074.

38 al-Șan‘ani, Muḥammad ibn Ismā‘̄il al-Amīr. 2005. Subul al-Salām. Jordan: Bayt al-Afkār al-Dawliyyah,.p.718.

39 al-Jawziyah, Ibn Qayyim. 1992. Zād al-Ma 'ād fì Hādy Khayr al- 'Ibād. Vol. 5, Bayrūt: Mu' assasat al-Risālah. p.577.

${ }^{40}$ Ibn Humām al Hanafî, Kamāl al- Dīn Muḥammad bin Abdul Wahīd. t.th. Sharḥ Fatḥu al Qadīr. Vol. 3. Bayrūt: Dār al Fikr. p. 438.
} 
dan Maliki ${ }^{41}$ menyatakan bahawa sabit pengharaman disebabkan penyusuan adalah tidak berdasarkan sama ada banyak atau sedikit susuan tersebut atau kadar susuan yang diberikan bahkan jika sekali sahaja hisapan sudah berlaku pengharamannya.

Pendapat ini disokong oleh beberapa fuqaha antaranya fuqaha mazhab Maliki, al-Awzā‘ $i$ dan Sufian al-Thawri. Begitu juga dengan sahabat yang menyokongnya termasuk Ibn Mas' $\bar{u} d$, Ibn 'Abbas, dan Ibn 'Umar. ${ }^{42}$ Mereka berhujah dengan ayat al-Qur'ān yang berikut, maksudnya: Dan ibu-ibumu yang telah menyusukan kamu dan saudara- saudara susuan kamu. 43

Berdasarkan kepada ayat ini jelas menunjukkan bahwa pengharaman daripada penyusuan itu tidak kira ia sedikit atau banyak. Mereka berhujah dengan umum ayat dan menerimanya secara mutlak. ${ }^{44}$

Pandangan kedua iaitu pandangan mazhab al-Shafi'i dan Hanbali pula mengatakan bahawa sabit pengharaman disebabkan penyusuan ialah apabila seorang bayi menghisap susu sebanyak lima kali susuan dalam lima waktu yang berlainan. Ini juga boleh dimaksudkan dengan lima kali kenyang, maka dikira pengharamannya. Pendapat ini disokong oleh beberapa orang sahabat seperti Sayyidatina 'Aishah dan Ibn al-Zubayr. Begitu juga dengan sebahagian besar fuqaha serta tabi'in seperti Imam Ahmad dan Sa‘īd bin Musayyib. ${ }^{45}$ Ini adalah pandangan yang rajih. Mereka berhujah dengan hadis sahih yang diriwayat oleh 'Aishah $\mathrm{RA}^{46}$

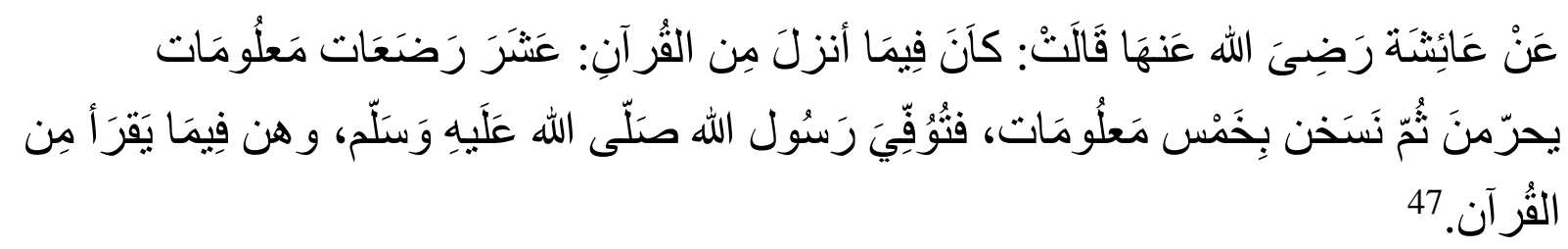

Maksudnya:

Diriwayatkan daripada 'Aishah RA. katanya: Terdapat dalam keterangan ayat-ayat yang diturunkan daripada al-Qur'ān adalah: sepuluh kali susuan yang maklum akan mensabitkan pengharaman. Kemudian dinasakhkan dengan lima kali susuan. dan Rasulullah SAW wafat sedang ayat itu masih dibaca dalam al-Qur'ān.

\footnotetext{
${ }^{41}$ al- Aṣbaḥ̄, Mālik bin Anas. t.th. al-Mudawwanah al-Kubrā. Vol.2. Bayrūt: Dār al- Fikr. p. 288.

${ }^{42}$ Op.cit. al-Jawziyyah, Ibn Qayyim. Zād al-Ma'ād fì Hādy Khayr al-'Ibād. p.571; al-Sarțāwī, Mahmud 'Ali. 2007. Sharh Qānūn al-Aḥwal al-Shakhsiyyah. 'Amman: Dār al-Fikr. p.65; al-'Asqalān̄̄, Shiḥ̄āb al- Dīn Aḥmad bin 'Alī bin al Hajar. 2000. Ibānat al-Aḥkām Sharh Bulūgh al-Marām. Vol. 3. Bayrūt: Dār al-Fikr. p.440.

${ }^{43}$ al-Qur'ān, al-Nisā' 4:23

${ }^{44}$ Op.cit. al-Jawziyyah, Ibn Qayyim. Zād al-Ma ‘ād fì Hādy Khayr al-'Ibād. p.571.

${ }^{45}$ Op.cit. al-Sarțāwī, Mahmud 'Ali. Sharh Qānūn al-Aḥwal al-Shakhsiyyah. p. 65.

${ }^{46}$ Ibid. p. 65.

${ }^{47}$ al-Bukhāri, Saḥịh al-Bukhārī, kitab nikah, bab tahrīm bi khamsi Raḍā 'āh, no hadis: 1452.
} 
TAMADDUN : Jurnal Pendidikan dan Pemikiran Keagamaan

P-ISSN : 1693-3941; E-ISSN : 2722-2632

Vol. 22 No.1 Bulan Januari Tahun 2021

\section{Interpertasi sunnah nabawiyah dalam mewujudkan Hubungan Mahram dengan} Anak Angkat dan Anak Susuan

Dewasa ini ramai pasangan yang tidak dikurniakan cahaya mata mengambil anak angkat untuk mengisi kekosongan dalam hidup mereka. Walaupun mereka memelihara dan membesarkan anak tersebut dengan penuh kasih sayang namun anak tersebut tetap menjadi orang asing atau ajnabi kepada ibu mereka. Perkara ini telah diberi amaran oleh Allah SWT dalam beberapa firmannya pada ayat ke 4,5 dan 40 Surah al-Ahzāb. Firman Allah SWT, maksudnya: dan ia juga tidak menjadikan anak-anak angkat kamu, sebagai anak sendiri. (Segala yang kamu dakwakan mengenai perkara-perkara) yang tersebut itu hanyalah perkataan kamu dengan mulut kamu sahaja. Dan ingatlah Allah menerangkan yang benar dan Dialah jua yang memimpin ke jalan yang betul ${ }^{48}$

Menurut al-Mazharī, ayat ini diturunkan karena orang arab jahiliyyah pada ketika itu menganggap anak angkat sebagai anak sendiri dan diberi pusaka dan dibinkan dengan nama mereka. Bahkan Nabi SAW sendiri juga mempunyai anak angkat bernama Zaid bin Hārithah. Mereka memanggilnya Zaid bin Muhammad. Untuk menafikan perkara tersebut Rasulullah telah berkahwin dengan Zainab binti al Jahsyi yang merupakan bekas istri kepada Zaid bin Hārithah. ${ }^{49}$

Keadaan ini juga berlaku dalam kalangan masyarakat hari ini. Karena kasih sayang yang tidak berbelah bahagi antara anak dan ibu bapa angkat ini menyebabkan mereka lupa antara mereka tidak ada ikatan darah serta tertakluk kepada pelbagai sekatan dan hukum di dalam Islam. Hubungan kekeluargaan yang dibina telah bertukar menjadi hubungan yang tidak diredai Allah SWT. Pendedahan aurat dan sentuhan seperti bersalaman antara anak dan ibu bapa angkat tetap merupakan sesuatu yang dilarang dalam Islam. Tapi perkara ini masih berleluasa dalam masyarakat Islam hari ini.

Sebenarnya segala permasalahan ini boleh dielakkan dengan pemberian susu ibu kepada anak angkat tersebut. Walaupun susu ibu tidak mampu menjadikan anak angkat seperti anak kandung atau boleh mewarisi pusaka, namun ia berupaya mewujudkan ikatan sosial yang kuat dengan anak angkat dengan menghalalkan ikatan kekeluargaan mereka dan banyak masalah sosial boleh diatasi. Ini adalah hikmah yang terbesar kenapa Allah SWT menjadikan susu ibu yang merupakan penghubung nasab antara seorang anak dan ibu. Terdapat dalam kalangan ibu yang mempunyai kesadaran ini, namun mereka menghadapi pelbagai masalah seperti sukar untuk mengeluarkan susu sendiri. Masalah ini sering terjadi kepada ibu yang tidak pernah melahirkan anak.

Dalam kehidupan manusia yang serba modern, pelbagai kaidah saintifik telah diperkenalkan untuk membantu manusia mencapai apa saja yang dihajati. Manusia tidak dapat

\footnotetext{
${ }^{48}$ al-Qur'ān, al-Aḥzāb 33:4.

49 al-Mazhharī, Muhammad Thana' Allah. 2007. Tafsir al-Mazhari. Vol.5. Bayrut: Dar al-Kutub al-Ilmiyyah. p. 481.
} 
menolak keupayaan ilmu yang dimiliki oleh para bijak pandai terutama dalam hal yang berkait rapat dengan kehidupan seharian termasuklah dalam soal penyusuan. Para ibu boleh mencoba kaidah penyusuan paksaan atau lebih dikenali sebagai induced lactation yang telah dijelaskan sebelum ini. ${ }^{50}$ Selain daripada penyusuan paksaan terdapat satu lagi cara modern untuk membolehkan susu keluar dari badan ibu dengan lebih mudah walaupun tidak pernah melahirkan anak atau berkawin yaitu dengan cara suntikan hormon penggalak susu. Persoalan juga timbul apabila seorang wanita yang belum berkawin tetapi hendak mengambil anak angkat. Lalu mereka mengambil hormon yang boleh menggalakkan pengeluaran susu lalu mereka menyusukan anak angkat mereka dengan susu tersebut supaya anak tersebut menjadi mahram kepada mereka. Apakah hukum dan implikasinya kepada pensabitan nasab anak tersebut?

Muzakarah Jawatankuasa Fatwa Majlis Kebangsaan memutuskan bahwa wanita yang belum berkawin tetapi mengambil pil atau suntikan hormon untuk menyusukan anak angkat mereka dibenarkan berbuat demikian. Menurut kenyataan Jabatan Kemajuan Islam Malaysia (JAKIM) melalui e-fatwa ${ }^{51}$, penggunaan obat atau suntikan yang tidak mempunyai unsur haram untuk merangsang pengeluaran susu badan adalah harus dengan syarat wanita tersebut telah mencapai umur baligh sama ada telah berkawin atau sebaliknya. Bagaimanapun, katanya, keharusan tersebut tidak tertakluk kepada seorang lelaki yang mengubah jantina kepada wanita. Keputusan tersebut diambil berdasarkan pandangan majoriti ulama yang tidak mensyaratkan seseorang wanita itu mesti hamil terlebih dahulu untuk menyusukan anak.Ini adalah pendapat mazhab Hanbali, Shāfi'‘̄i, Maliki dan Hanafi. ${ }^{52}$

Jelas kenyataan itu, Muzakarah Jawatankuasa Fatwa Majlis Kebangsaan Bagi Hal Ehwal Agama Islam Malaysia Kali Ke-96, telah membincangkan mengenai hukum wanita menyusukan anak angkat. Anggota majlis Fatwa katanya, turut memutuskan bahwa seorang lelaki yang mengawini wanita yang menyusukan bayi angkat tersebut secara tetap telah menjadi mahram kepada anak susuan tersebut. Bayi tersebut sah sebagai anak susuan apabila cukup syarat-syarat penyusuan yang ditetapkan oleh syarak seperti cukup bilangan susuan hendaklah dengan lima kali penyusuan, susu yang dihisap mestilah sampai ke perut bayi dan umur bayi tidak melebihi dua tahun mengikut perkiraan bulan qamariah (kalendar Islam).

Sekiranya kedua-dua cara ini masih belum mampu untuk mengeluarkan susu ibu, terdapat satu lagi inisiatif lain boleh dilaksanakan. Anak angkat lelaki boleh coba diberi susu ibu daripada adik-beradik ibu angkat tersebut. Dengan ini hubungan antara anak dan ibu angkat tadi ialah anak saudara susuan dan hubungan antara mereka adalah mahram susuan sama seperti

\footnotetext{
${ }^{50}$ Penjelasan yang lebih lanjut boleh dirujuk dalam bab II.

${ }^{51}$ Anon. 11 Disember 2011. 2011. www.e-fatwa.gov.my

52 al-Sharbīn̄̄, Muhammad al-Khatīb. 1978. Mughnī al-Muhtāj ilā Ma 'rifat Ma 'ānī Alfāz al-Minhā. Vol. 3. Bayrūt: Dār Ihyā' al-Turāth al-'Arabī. p.414; Ibnu Rushd, Abū al-Walīd Muhammad bin Ahmad. Bidāyatul Mujtahid fì Nihāyat al Muqtașid. Vol.2. Dār al-Fikr. p.30; al -Zarqā', Mușțafā. 2004. Fatāwā Muștafā al-Zarqā'. Damsyik: Dār al-Qalam. p.293-294.
} 
hubungan antara anak saudara dan ibu saudara. Demikian juga dengan anak angkat lelaki, susu ibu boleh diberikan daripada mana-mana adik beradik bapa angkat yang mempunyai susu ibu. Maka hubungan mahram akan terwujud di sana dan ikatan kekeluargaan menjadi lebih bersih daripada perkara yang diharamkan di dalam Islam. ${ }^{53}$ Amalan ini pernah berlaku di zaman Rasulullah SAW dan telah diriwayatkan oleh Sayidatina Aisyah RA:

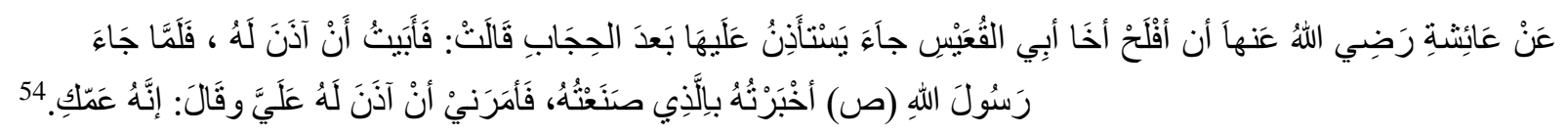

Maksudnya: dan diriwayatkan daripada Aisyah (RA), bahawasanya telah datang kepadanya seorang lelaki bernama Aflah. Aflah ialah adik beradik kepada Abi Qu'ais yang merupakan bapa susunya. Aflah meminta izin untuk memasuki rumahnya dan ketika itu ayat berkaitan hijab telah diturunkan. Aisyah berkata: Aku enggan untuk memberi izin kepadanya untuk memasuki rumah. Maka ketika Rasulullah datang, aku khabarkan kepadanya apa yang telah aku lakukan. Maka beliau menyuruhku memberi izin supaya dia (Aflah) memasuki rumah. Sesungguhnya ia (Aflah) adalah bapa saudaramu.

Daripada hadis ini dengan jelas dapat diperhatikan bahwa bapa saudara sepersusuan merupakan salah seorang daripada mahram susuan. Maka dalam keadaan ini bapa angkat tadi menduduki tempat sebagai bapa saudara susuan dan menjadi mahram kepada anak angkat tadi.

Selain itu terdapat juga satu kisah di mana Rasulullah SAW disuruh berkawin dengan puteri kepada Sayyidina Hamzah RA. Tetapi beliau menolaknya karena Hamzah adalah saudara sepersusuannya dan puteri tersebut adalah anak saudara susuannya. Diriwayatkan daripada Ibnu Abbas, Rasulullah SAW bersabda:

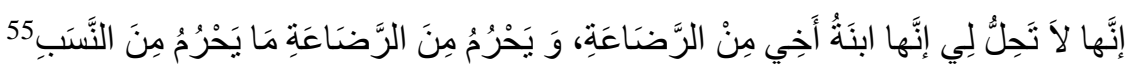

Maksudnya: bahawasanya ia tidak halal bagiku karena ia adalah anak saudaraku sepersusuan. Dan diharamkan daripada susuan itu sama seperti haram daripada nasab.

\section{Prosedur Pengambilan Anak Angkat Di Malaysia}

Di Malaysia, secara umumnya, terdapat dua cara untuk mendapatkan anak angkat. Pertama, mendapatkan anak tersebut dengan cara sendiri yaitu terus dari ibu bapa yang sanggup memberikan anak mereka sebagai anak angkat. Kedua, dengan memohon kepada JKM. Dalam menjalankan fungsi menempatkan anak angkat kepada keluarga angkat ini, faktor utama yang diambil kira oleh JKM ialah kebajikan anak tersebut. Untuk itu, berbagai maklumat coba didapatkan dari pasangan yang berminat bagi memastikan kebajikan kanak-kanak itu terpelihara. Justru, selain mengisi borang, pasangan yang memohon untuk mendapatkan anak

\footnotetext{
${ }^{53}$ al-Sharbajīi, 'Ali, Muștafā al-Khīn \& Mustafa Bughā. 1987. al-Fiqh al-Manhajī 'ala Madhdhab al-Imām al-Shāfi 'ĩ. Vol. 4. Damsyiq: Matba'ah al-Sabl. p.206.

${ }^{54}$ Bukhārī, Saḥ̄h Bukhārī, Kitāa nikāh, bā̄b al-rị̂ā, no. hadis: 1044.

${ }^{55}$ al-Muslim, Saḥ̄h Muslim, Kitāb al-riḍā, no hadis: 1447
} 
angkat ditemuduga bagi penyediaan laporan sosial mereka. Antara maklumat yang coba diperolehi ialah latar belakang sosial mereka serta kesanggupan mereka menjadi keluarga angkat di samping memenuhi syarat dalam Akta Perlindungan Kanak-kanak 1991 dan Akta Pengangkatan 1952 (untuk bukan Islam) atau Akta Pendaftaran Pengangkatan 1952 (untuk orang Islam). ${ }^{56}$

Di samping mendapatkan maklumat pemohon, pemohon juga dimaklumkan tentang perkara-perkara lain seperti implikasi menjadi keluarga angkat, tugas dan tanggung jawab mereka sebagai keluarga angkat, latar belakang bayi/kanak-kanak di bawah jagaan JKM serta hakikat bahwa pemohon tidak boleh memilih bayi dari paras rupa fizikal tetapi boleh memilih dari segi umur dan jantina.

Antara perkara yang dinilai oleh JKM tentang para pemohon ialah: a) Hubungan perkawinan pemohon adalah kukuh dan bahagia b) Mereka mampu memberi kasih sayang kepada anak angkat itu nanti c) Permohonan dibuat dengan ikhlas dan sepenuh hati dan bukannya karena paksaan atau tekanan mana-mana pihak d) Kedua-dua pihak (suami dan istri) setuju dengan permohonan tersebut e) Mereka paham implikasi dan cabaran menjadi keluarga angkat dan yakin dapat mengatasi masalah tersebut secara keluarga.

Bagi menilai sama ada pasangan tersebut layak atau tidak memperolehi anak angkat, kriteria-kriteria berikut digunakan: a) Pasangan tersebut disahkan tiada kemungkinan melahirkan anak (untuk itu pengesahan perubatan didapatkan dari mereka bagi memastikan yang mereka telah berusaha berbagai cara untuk mendapatkan anak tetapi tidak berhasil). b) Pasangan tersebut sudah berkawin selama 5 tahun atau lebih tetapi masih belum mempunyai anak. c) Pasangan tersebut mampu memberi belaian kasih sayang, jagaan dan perlindungan yang sempurna. d) Pasangan tersebut mampu memelihara anak tersebut dari segi ekonomi, kesehatan, sosial, emosi, mental dan lain-lain. e) Pasangan yang mempunyai anak kandung diberi pertimbangan sekiranya mereka sanggup mengambil kanak-kanak yang sudah besar.

Berdasarkan kepada statistik yang ada, JKM menerima banyak permohonan untuk mendapatkan anak angkat. Malah, permohonan ini adalah melebihi daripada apa yang dapat dipenuhi oleh JKM sendiri. ${ }^{57}$

\section{SIMPULAN}

Kesimpulannya, setiap pasangan yang telah berumah tangga pasti berharap mereka akan mempunyai anak kandung mereka sendiri. Namun bukan semua kehendak takdir menepati kehendak dan naluri seseorang manusia. Realitasnya banyak dalam kalangan pasangan yang berumah tangga pada hari ini gagal untuk memperolehi cahaya mata mereka sendiri. Akhirnya untuk memenuhi naluri keibuan dan kebapaan, mereka telah mencari jalan untuk memiliki anak

\footnotetext{
${ }^{56}$ Siti Fatimah Abd Rahman. 8 Julai 2014. http://www.ikim.gov.my/index.php/ms/artikel/7115.

${ }^{57}$ Siti Fatimah Abd Rahman. Julai 2014. http://www.ikim.gov.my/index.php/ms/artikel/7115.
} 
TAMADDUN : Jurnal Pendidikan dan Pemikiran Keagamaan

P-ISSN : 1693-3941; E-ISSN : 2722-2632

Vol. 22 No.1 Bulan Januari Tahun 2021

angkat dan membelanya seperti anak sendiri. Sebenarnya pengambilan anak angkat ini sangat mulia di sisi Islam bahkan Nabi SAW sendiri pernah mempunyai anak angkat seperti Zaid bin Harithah. Namun apa yang malangnya ialah apabila mereka yang mempunyai anak angkat ini tidak lagi mampu untuk menjaga batas-batas pergaulan antara mereka terutamanya apabila anak tersebut meningkat dewasa. Perbuatan seperti anak angkat lelaki yang bersalaman dan berpelukan dengan ibu angkatnya sebenarnya merupakan suatu perkara yang mungkar tanpa kita sedari. Justru itu untuk mengelak daripada berlakunya kemungkaran dan kemaksiatan dalam keluarga sendiri, pengamalan ibu susuan seperti mana yang diamalkan oleh Nabi SAW dan para sahabat perlu diamalkan sepenuhnya. Dengan ini naluri keibuan dan kebapaan dapat disalurkan dengan cara yang betul dan kehendak syarak juga dapat dipenuhi. Dengan cara ini keluarga yang mengambil anak angkat akan lebih diberkati hidupnya serta jauh daripada kemurkaan Allah SWT.

\section{REFERENSI}

Al-'Asqalānī, Shị̣āb al- Dīn Aḥmad bin 'Alī bin al Ḥajar, 2000. Ibānat al-Aḥkām Sharḥ Bulūgh al-Marām, Jil. 3, Dār al-Fikr, Bayrūt.

Abdul Hamid Arshat, 1991. Baka dan Zuriat, Kuala Lumpur, Syarikat S. Abdul Majeed.

Abū al-'Abbās, Shams al-Dīn Muḥammad,1984. Nihāyat al-Muhtāj 'ilā Sharh al-Minhāj fì madhhab al-Imām al-Shāfi 'ì, Jil. 7, Bayrūt, Dār al-Fikr.

Al-Sarțāwī, Mahmud 'Ali, 2007. Sharḥ Qānūn al-Aḥwal al-Shakhsiyyah, Dār al-Fikr, 'Amman.

Anon, 2011, www.e-fatwa.gov.my [11 Disember 2011].

Anon. Melayu paling ramai mohon anak angkat, 19.5.2011. http://www.utusan.com.my/utusan/info.

Al-Aṣbaḥ̄, Mālik bin Anas, t.th. al-Mudawwanah al-Kubrā, Jil.2, Dār al- Fikr, Bayrūt.

Al-Baḥūtī, Manșūr ibn Idrīs, 2003. Kashshāf al-Qinā' 'an Matn al-Iqnā', Dār 'Alam al-Kutub, Arab Saudi.

Choudhry, G.W, 1993. The Prophet Muhammad, His Life and Eternal Message, WHS Publication Sdn. Bhd, Kuala Lumpur.

Al-Dardīr, Abū al-Barākāt Aḥmad ibn Muḥammad, t.th. al-Sharh al-Saghir 'alā Aqrab alMasālik ila Madhhab al-Imām Malik, Bayrūt, Dār al-Ma'ārif.

al-Dusūqī, Shams al- Dīn Muhammad al-'Arafah. T.th. Hāshiyat al-Dusūqū 'alā al-Sharh alKabīr. Jil. 2. T.tp: Dār al-Kutub al-'Arabiyyah.

Al-Ghazālī, Abū Ḥāmid Muḥammad bin Mạ̣mūd, 2001. al-Waṣịt Fī al-Madhhab, Jil. 3, Dāral Kutub al 'Ilmiyyah, Bayrūt. 
Al-Ghunaymī, 'Abd al-Ghanī al-Dimashqī al-Maydānī al-Hanafì, 1993. al-Lubāb fì Sharh alKitāb, Maktabah al-'Ilmiyyah, Bayrūt.

Al-Ḥusaynī, Taqī al-Dīn Abū Bakr ibn Muḥammad, 1995. Kifāyat al-Akhyār, Dār al-Khayr, Bayrūt.

Ibn Humām al Hanafì, Kamāl al- Dīn Muḥammad bin Abdul Wahīd, t.th. Sharḥ Fatḥu al Qadīr, Jil. 3, Dār al Fikr, Bayrūt.

Ibn Manẓūr, Muḥammad ibn Mukram,2003. Lisān al- 'Arab, Dār al-Hadīth, Kaherah.

Ibn Qudāmah, 'Abd Allah ibn Ahmad. 2004. al-Mughnī. Jil. 2. Ammān: Bayt al-Afkār alDawliyyah.

Ibnu 'Ābidīn, Muḥammad Amīn, 1992. Hāshiyat Radd al Mukhtār 'ala al-Durr al Mukhtār: Sharh Tanwīr al Abṣār, Jil. 3, Dār al- Fikr, Bayrūt.

Ibnu Rushd, Abū al-Walīd Muḥammad bin Aḥmad,t.th. Bidāyat al-Mujtahid fì Nihāyat al Muqtașid, Jil.2, Dār al-Fikr.

Al-Jawziyyah, Ibn Qayyim. 1992. Zād al-Ma'ād fì Hādy Khayr al-'Ibād. Jil. 5. Bayrūt: Mu'assasāt al-Risālah.

Al-Kāsānī, 'Alā' al- Dīn, Abu Bakr ibn Mas'ūd. 1986. Badā'i' al-Sanā' 'í. Jil. 4. Bayrūt: Dār al-Kutub al-'Ilmiyyah.

Al-Mawardī, Abu al-Hasan 'Ali ibn Muhammad ibn Habib. 1996. Kitāb al-Raḍa'. Dār Ibn Hazm.

Al-Maẓharī, Muhammad Thanā’ Allah. 2007. Tafsir al-Maẓharī. Jil. 5. Bayrūt: Dār al-Kutub al-'Ilmiyyah.

Muḥammad, Abdul Raḥmān Kamāl,1971. Taysīr al- Fiqh al-Shafi 'i Lì țālib wa al-Sà ‘ì, Dār alKutub al-'Ilmiyyah, Bayrūt.

Muhammad Husain Haekal,1989. Sejarah Hidup Nabi Mohammad, Dewan Bahasa dan Pustaka Kuala Lumpur.

Al-Rāzī, Muhạmmad ibn Ab̄̄ Bakr ibn 'Abd al-Qadīr, 1995. Mukhtar al-Ṣihah, Maktabat Lubnan, Bayrūt.

Rị̣ā, Muḥammad Rashid, 2005. Tafsīr al-Manār, Jil. 2, Dār al-Kutub al-'Ilmiyyah, Bayrūt.

Sa'dī Abū Jayb. 1988. al-Qāmūs al-Fiqhī Lughotan wa Iștilāhanan, Dār al- Fikr, Damsyiq.

Al-Șan'ani, Muḥammad ibn Ismā‘n̄l al-Amīr, 2005. Subul al-Salām, Bayt al-Afkār alDawliyyah, Jordan.

Al-Shāfi'‘̄, Abū 'Abd Allah Muhammad ibn Idrīs, t.th. al-Umm, Jordan, Bayt al-Afkār alDawliyyah.

Al-Sharbaj̄̄, 'Ali, Mușțafā al-Khīn \& Mustafa Bughā, 1987. al-Fiqh al-Manhajī 'ala Madhdhab al-Imām al-Shāfi ‘̄, Jil. 4, Matba'ah al-Sabl, Damsyiq. 
TAMADDUN : Jurnal Pendidikan dan Pemikiran Keagamaan

P-ISSN : 1693-3941; E-ISSN : 2722-2632

Vol. 22 No.1 Bulan Januari Tahun 2021

Al-Sharbīn̄̄, Muhammad al-Khatīb, 1978. Mughnī al-Muhtāj ilā Ma'rifat Ma'ānī Alfāz alMinhāj, Jil. 3, Dār Ihyā’ al-Turāth al-'Arabī, Bayrūt.

Siti Fatimah Abd Rahman, http://www.ikim.gov.my/index.php/ms/artikel/7115.[8 Julai 2014]

Syeikh Alaudeen,1996. Penyusuan Ibu Aspek Pemakanan, Perkembangan dan Kesihatan Bayi,

Dewan Bahasa dan Pustaka, Kuala Lumpur.

Al-Zarqā', Muștafā, 2004. Fatāwā Muștafā al-Zarqā', Dār al-Qalam, Damsyik.

Al-Zaydān, 'Abd al-Karīm. 2003. al-Mufașsal fì Aḥkām al-Mar'ah wa al-Bayt al-Muslim fì al-

Sharī'ah al-Islāmiyyah. Jil. 5. Bayrūt: Mu'assat al-Risālah.

Al-Zaylā'ī, Jamāl al-Dīn Abū Muhammad 'Abd Allāh al-Hanafì, 2000. Tabyīn al-Haqā'iq Sharh Kanz al-Daqā'iq, Dār al-Kutub al-'Ilmiyyah, Bayrūt. 